\title{
Court modernisation and the crisis facing our civil
} courts

\author{
by Lord Justice Brooke
}

The Seventh Annual Lecture to be presented to the Society for Advanced Legal Studies was given by Lord Justice Brooke, Vice-President of the Court of Appeal (Civil Division), on November 24, 2004.

I have been asked to talk about the modernisation of the courts. I do not know what the opposite of an inaugural lecture is called. Perhaps I should call it "Good-bye to All That." At the end of last June I finished 19 years of promoting the use of technology in the legal system. I started it by being a member of the first committee ever set up to give advice to the Bar about computers. I ended it by being for four years a member of the small Board which has been taking forward the $£ 260$ million court modernisation programme. Tonight I have come to tell you something of the story.

I have written elsewhere ${ }^{1}$ about the reasons why there was such chronic under-investment in IT in support of the courts during the 1990s. Two years ago I was at a presentation given by the then director-general of Criminal Justice IT. This showed how far the courts had lagged behind the police, the CPS and all the other agencies which make up our criminal justice system. I lived through the lean years in which investment in IT was regarded by the Lord Chancellor's Department as investment on the margins, and they never had any money to spend on the margins. They could afford to instal IT networks in their own headquarters offices. But the courts, and particularly the front offices in the courts, where the judges work, were an IT desert.

I must mention four developments in the 1990s. The first was a back office system called CREST. This was installed in the Crown Courts 13 years ago. It enabled court staff to produce common form documents without having to type each of them out one by one. It also helped them to perform some other fairly basic back office tasks. Similar arrangements, called CASEMAN and FAMILYMAN, were installed in the back offices in the county courts about seven years ago. There was also an excellent computerised bulk claims centre at Northampton which processed straightforward debt collection claims by their thousands. This process led up to a computerised default judgment which never went anywhere near a court.
And a small amount of money was set aside to allow 400 judges to have their first direct experience of using a PC in their work.

A large part of the difficulty was that the Lord Chancellor's Department was chronically overwhelmed, year after year, by unbudgeted overspends on legal aid. MPs are good at encouraging ministers to devote more resources to causes they are interested in. But they never seemed to have much interest in what was needed to keep the courts functioning effectively. In those 19 years I was only ever asked once to speak to a group of parliamentarians. That was a delegation from the state of Victoria, which had crossed the world to learn about best practice in court modernisation. Later on I will tell you what I saw when I visited Melbourne last year.

It was about six years ago that things started to wake up. A team of civil servants examined what might be done to improve the efficiency of the Crown Courts. Among other things, they looked at the possibilities of investment in technology. On the civil justice side, Lord Woolf delivered his final report in 1996, and it was unthinkable that his reforms could ever be put into effect without heavy investment in IT to help judges and court staff. This was because huge new burdens were being placed upon the judges to enable them to control civil litigation from the centre. In 1988 a Government inquiry team had strongly recommended investment in court based IT to help the judges ${ }^{2}$. Nothing was then done, and things stood still for 10 years.

On the Crown Court side the team produced a report called "Transforming the Crown Court". This report caused an uproar, but its uncontroversial elements remained unscathed. Money was allocated immediately, and also in the Government spending review in 2000, to the start of a modernisation programme in the Crown Court. The idea was to produce a specification for wiring and cabling every Crown Court in the country. As a result 
each would have a modern networked IT infrastructure fit for the next thirty years. There was also to be investment in pilot schemes at a few Crown Courts to test the possibilities of different technologies. Digital audio recording ("DAR"), electronic presentation of evidence ("EPE"), and an electronic public information system which the politicians fancied were at the front of the list.

On the civil justice side valiant efforts were made in 1997 and 1998 to try and make plans for IT systems to support the Woolf reforms. These plans were always doomed. The rule-makers went on changing the rules right up to Woolf Day on 26 April 1999, and nobody can design complex IT systems under those conditions. Those of us who knew a little about IT were worried that yet another set of inadequate systems were to be rushed out with no prospect of leading anywhere afterwards. Professor Richard Susskind, who advised us, kept on saying that we should now be building the foundations for a 12-storey office block, and not another bungalow.

Eventually it was decided to call the whole thing off. We needed to do some really hard thinking about what had to be done to save our system of justice in the civil and family courts from falling apart for lack of investment. In the meantime the Lord Chancellor decided to go ahead with the civil justice reforms without the IT support they needed. The Head of Civil Justice, Sir Richard Scott, was known to disagree with that decision, because he really did not know how the courts would be able to cope. But Lord Woolf supported it on pragmatic grounds, and a fairly rudimentary system called High Court Forms was rushed out to support the High Court Masters who had never had to manage court files before. The judges received then what we thought was a very firm promise that we would receive the IT back-up we needed as soon as it was ready.

The boards responsible for modernising the Crown Courts and the civil and family courts were amalgamated in 2001 because there were so many points of similarity. But I think it would be better if I treated these two topics separately since the differences in their treatment have been so striking. What is common to both, however, is the professionalism of the team that has been driving the programme forward. During the last four years two of the civil servants and three of the judges who have been spearheading this work have been awarded the CBE or the OBE for public services. Two years ago the team running the $£ 160$ million project concerned with installing IT infrastructure in the courts won an award from the Cabinet Office for the best managed IT project within Government that year. Some of the team's projects, like the Money Claims Online system, have won international praise. And the Court Service has won awards from US judges in two separate years for producing one of the best designed "foreign" court websites. It will be an important theme of this lecture that in this team, with whom I worked closely for four years, we had a resource of international quality. It is a tragedy that it is now being broken up because funding is simply not available to take their work the next logical step forward.

Four years ago the team was allocated enough money to start implementing their plans in the Crown Courts during the three years which began in April 2001. Two years later the Government made a massive investment in criminal justice IT for the three year period starting in April 2003. By this time Government had absorbed a message Sir Brian Neill and I started trying to teach it in 1986. This was that the different players in the court system are interdependent. It is foolish for one part of the system, whether it is the police or the CPS or the Court Service, to design its IT systems as if they are in an oasis, totally isolated in its private patch of desert from anyone else. In 1986 we founded the IT and the Courts Committee ("ITAC") to take forward this message, but nobody listened. In the same year we were very critical of the designers of the CREST system, because they were making no provision at all for the flow of information electronically into the courts from other court users. We had to wait for 15 years for that mistake to be put right.

What was arranged two years ago was that there was to be a $£ 1.1$ billion investment in criminal justice IT over the next three year period. This was not all new money, because a lot of it had already been allotted for 2003-4, but it was much more than had ever been provided before. The money was to be held by a new organisation called Criminal Justice IT for the benefit of the Home Office, the Lord Chancellor's Department and the Law Officers' Department. None of it could be allocated without the agreement of a minister from each department and also the Director-General of Criminal Justice IT.

Most of the main spending allocations were made early on. Because our basic IT infrastructure was so far behind everyone else, we were allotted the funding to instal it in all our Crown Courts by April 2006. But that was about it, so far as the criminal courts were concerned, with one exception. There was no new money for DAR. No new money for EPE. No money at all for the case handling systems we so badly needed. No new money for videoconferencing, either, although in due course money was secured from a different budget to provide 30 Crown Courts with video links with prisons.

The one exception to all this was the XHIBIT project. This project had always been a political favourite. It provided very few benefits for judges and court staff, and we would have greatly preferred to invest the money elsewhere. But the project was perceived to benefit the public, and to be a good example of a "joined up" project in which investment in one part of the criminal justice system would benefit people in other parts of it. So a green light was given to it, and although it then ran into serious delays, approval has now been given for a national roll-out. This will start in two weeks' time with courts in the NorthEast. 
I will say a little now about the various initiatives in the Crown Court ${ }^{3}$, taking the story through to April 2006, when the first slice of CJIT funding runs out. The next slice, incidentally, is much smaller.

The IT infrastructure project is called the LINK project. Before the programme started three years ago, the only PCs that were to be seen in a Crown Court were the dumb terminals linked to the CREST database, the judges' freestanding laptops, and perhaps a handful of freestanding PCs at some court centres for senior members of the court's staff. It was and is difficult to recruit and retain staff to work in such an out of date working environment. When I visited the Snaresbrook Crown Court, the first court to be completed, in the autumn of 2002, the enthusiasm of the staff was palpable. They said "We never thought the Court Service cared for us so much", although they were only receiving working tools which had already been in common use for a long time in comparable organisations. Leicester came next, followed by Doncaster, Coventry, Chelmsford and Birmingham. In the summer of 2003 the Old Bailey was closed down for four weeks while all its courtrooms were wired and cabled, and also equipped with video link equipment.

The LINK project is now going full steam ahead. It is brilliantly managed, and the work is being done to time and well within budget. Because this is such a success story, you do not hear about it. I dreaded the complaints that were going to come my way from judges as court after court was going to be disrupted. But we were able to set up excellent arrangements for judicial liaison, and with the odd hiccup the programme has run smoothly. By March 2006 every Crown Court in the country will have a modern infrastructure of the kind I have described. A Crown Court centre's network now embraces the courtroom and the judges' chambers. It is no longer restricted to the court's back offices.

I will speak about XHIBIT next. This was first launched three years ago at the Chelmsford Crown Court. It was developed as a result of discussions between the different criminal justice agencies, all of whom have an interest in knowing the progress a Crown Court trial is making, and its eventual result. Witnesses need to get to court at the right time. Police officers who have to give evidence should not be away from their other duties for too long. Those who are concerned in the next case in the list have an interest in knowing whether the current trial is running to time. And so on.

XHIBIT is a web-based system which depends on someone keeping a log of key events in the courtroom. These events are then transmitted immediately to the XHIBIT screen. Examples of key events are the prosecution opening speech; prosecution lay evidence; police evidence; defence evidence; closing submissions by the prosecution; judge's summing up; jury in retirement; verdict; sentencing. The information on XHIBIT is accessible on monitor screens in the public parts of the court building and in the jury assembly area, and also on the website of the Crown Court. Text messages can be sent to people who need to be warned when to attend court.

XHIBIT was then extended to two other Crown Courts in the Essex area, and after a very long delay an enhanced version went live at the Snaresbrook Crown Court just over a year ago. XHIBIT delivers no immediate benefit to the judiciary, and it will cost the Court Service dearly because there will always have to be a trained logger in the courtroom. But some experienced Crown Court judges saw great potential value in the new version.

The sentence of the court, for instance, is immediately available to everyone with an interest in the case long before the security van delivers convicted prisoners to the prison at the end of the court day. Last year I attended a talk on "The First Night in Holloway Prison". A researcher described the confusion which accompanies the arrival of a prison van at Holloway in the early evening. Women prisoners often make no arrangements for their families, because they have shut out of their minds the idea that they may go to prison, and nobody knows who they are until they arrive. She said it would improve things greatly if modern information systems could alert a prison to the number of prisoners it was due to receive, and who they were, some time before they actually arrived. XHIBIT now meets this need, provided that prison staff get into the habit of accessing the electronic information flow at the appropriate time.

The only way in which XHIBIT can justify itself is if it is very widely used in practice. Its cost-benefit justification depends heavily on the savings in unproductive time spent by witnesses, particularly police witnesses, waiting to be called to give evidence, and on the efficiencies which should flow from a far better information system if it is fully used. A prisoner's conviction and sentence, for instance, should now be transmitted almost immediately to the national police records database. This should put an end to the inefficiencies that are very familiar to every Crown Court judge.

An integral part of the XHIBIT arrangements is to be provided by a CJIT project called Criminal Justice Exchange. This will furnish the platform for the exchange of information relating to criminal proceedings between the different agencies. The agencies which represent Government will be able to correspond with each other behind the firewalls of the Government Secure Intranet. A crucially important aim of this project is to ensure that barristers and solicitors in private practice can also obtain access to the information they need.

The secure email arrangements for lawyers in private practice looked set to founder at one stage under a mountain of form-filling. Take-up has continued to be very slow. The judges have been doing their best to persuade the planners that they have got to make the arrangements 
much simpler to use if they are to expect any take-up at all from solicitors' firms and sets of chambers.

Next, EPE. Between 2000 and 2001 EPE equipment was installed in a courtroom in nine different Crown Court centres. In some of the selected trials the defendants pleaded guilty. In another the trial judge refused to allow the prosecution to use the equipment because he feared that it might lead to an unfair trial. Sufficient experience was gained from the other trials, however, for its value to be assessed. Juries like this kind of presentation, and its use saves a great deal of court time. One judge reported in October 2002 that a four-month trial anticipated to last into the New Year was likely to be completed before the end of November, largely thanks to EPE.

That year I went to Blackfriars Crown Court in London to watch an hour of a VAT fraud trial in which the prosecution was using EPE. There was an excellent computer operator in court, who would call up each imaged document when counsel identified it by number. It would then be immediately available on all the small screens in court (including one for every two members of the jury, and one for the defendant in the dock). If anyone produced a new document, it would be immediately scanned in and displayed electronically. I spoke afterwards to counsel, the judge and court staff. It was obvious that everyone was delighted by this service, which had enabled the trial to move much more smoothly - and more quickly. The jury liked it a lot, and it made their task much easier.

No new money was provided for EPE by the Treasury in 2002. But once a Crown Court centre has been equipped with a modern IT infrastructure, there is no reason why a prosecuting authority should not instal the hardware into a networked courtroom if it believes that this would make the trial run better. A protocol governing the use of EPE in criminal trials has now been prepared and published.

EPE is often used alongside Livenote, which produces a transcript of the evidence very soon after a witness speaks it. This is now a regular feature of all our big inquiries, and the largest of our criminal trials. I suspect that EPE is likely to be used more often in our civil courts in future, because the US evidence as to the value of visual presentation of evidence seems to be all one way. At present there is a bit of a standstill in all this for lack of funding.

Turning now to modern recording equipment, DAR was tested on a pilot basis at three Crown Court centres. The equipment was expensive, partly because the Court Service could not obtain good quantity discounts for a comparatively small order. No more money was then allocated in the 2003-6 period for any further use of DAR. It is likely that in due course our courts will go over to DAR as a recording medium, because its efficiency savings and other benefits are so obvious.

A Tasmanian judge told me last year that in Tasmania a trial judge's sentencing remarks are recorded by DAR and immediately sent by telephone to a transcribing centre. The transcript will then be put before the judge for approval, and it will be published on the court website before the end of the day. ${ }^{4}$ This means that the media have access to an accurate record of what the judge actually said. It also makes the judge's sentencing comments available immediately to everyone in the criminal justice agencies who are concerned with handling the convicted defendant following the sentence.

At Snaresbrook 20 courtrooms were fitted with "whispering witness" technology as part of the DAR experiment. This was very successful, particularly in sex offence trials. Shy witnesses with soft voices no longer had to shout out the intimate details about the way they said the defendant treated them. It is a pity that there is no funding for extending the use of this technology to all our courts. As a trial judge 15 years ago I was always concerned about the way in which we had to treat the complainants in rape cases for want of suitable technology in court. But apart from Snaresbrook nothing much seems to have been done about this, except that a number of Crown Courts have now taken the initiative and installed relatively cheap but effective wireless amplification. The technology is there. The will to pay for it isn't.

There was a one-off experiment at Manchester testing the possibilities of the Internet for the conduct of plea and directions hearings on-line. I think that about 140 different people (barristers, solicitors, court staff and the judge) had access to this closed website for the cases with which they were concerned. There was some publicity for this in the newspapers when the judge gave directions in one case online while on a holiday abroad. That was an interesting experiment, but it is generally accepted that it does not show the way to the future. Much more promising is a new case progression pilot project, also being run at Manchester, this time by CJIT. This may teach us a lot about the best way to handle the preliminary stages of a criminal trial with IT support in future.

I have mentioned video-links with prisons. These are now in constant use in 170 magistrates' courts and 30 Crown Courts. The process attracted a lot of publicity when it was used at some of the early formal hearings in the Soham murder case. The use of the link saved the expense involved in arranging police escorts from a number of different county forces to accompany the prison van from Holloway to Peterborough for a short hearing. It also avoided the scenes requiring a significant police presence which had occurred when the defendant arrived outside the court for the original hearing. I advocated the use of this technology to the Home Office in 1986. It is nice to see that it has at last arrived, although 60 Crown Court centres are still without it.

I do not have many worries about the criminal courts. Government has shown that it is willing to finance them properly, and for obvious reasons not everything can be 
done at once. The installation of the LINK infrastructure, and the provision next year of a new generation of modern laptops to the whole of the full-time judiciary, will enable judges and court staff to get used to working in a modern networked environment even though the software tools they really need, in the form of proper case handling software, are still to come. In the meantime an excellent job is being done in providing training for judges to whom the use of a PC doesn't come as second nature. Court staff are also being provided with the training support that was often in very short supply in the past.

It is when I turn to the civil and family courts that things are much more bleak. This is not the fault of the Court Service, which has been trying its very best to cope, with completely inadequate resources. Like many other judges, I would like to pay a heart felt tribute to Court Service managers for keeping the show on the road at all. But they, like us, are the victims of a most peculiar system of funding the civil and family courts that has no parallel anywhere in the common law world.

What are the problems? In the first 10 years of practice at the Bar, I used to be sent the solicitors' original correspondence file attached by a pin in the top left hand corner. I then spent about 20 minutes taking out the pin and rearranging the papers in some sort of coherent chronological order. I used to do the same when I was on circuit as a High Court judge, and was asked to deal with an appeal from a district judge. I was given the court file, and the papers were all over the place. By then I understood the true economic cost of 15 minutes of a High Court judge's time. It was not being used sensibly.

Because judges have never been trusted with court administration, these very expensive inefficiencies have never been fed into any departmental cost benefit analysis. The business cases for CREST and CASEMAN were only established because it was easy to calculate how staff numbers could fall if IT systems were introduced to carry out very routine tasks. By the end of the 1990s it was obvious to senior court managers and senior judges that something really radical had to be done if the civil and family court systems were not to grind to a halt in a sea of unsorted paper.

I described the problems in my contribution to a book published last year. ${ }^{5}$ I said that the major review we undertook four years ago threw up important questions about the roles the judges were now required to play. Overall, there were many more judges in the lower level of the judicial hierarchy than there were 15 years ago. Judges are an expensive resource: far, far more expensive than the staff who serve them. Were we really making the best use of their time and skills? A clear message emerged that judges were spending much too much of their time sorting out muddled court files, or waiting for the information they needed, or doing things that could be done just as well whether court staff were being provided with the training and the technology they needed, and what could be done to improve job satisfaction, for staff and judges alike, throughout the system.

In January 2001 the Court Service published a consultation paper on Modernising the Civil Courts. This paper described the very serious difficulties very frankly. Six months later a judges' working group, led by Mr Justice Cresswell, published its own report. They started with a description of the problems which nearly every judge in the country faces every day. The list began: "Insufficient staff - high staff turnover leading to the use of inexperienced staff - missing or chaotic files - court orders take too long to be drawn and are often drawn incorrectly - lack of proper administrative support for the judiciary". Later on they said that very few members of court staff had real IT expertise, and that there was a chronic lack of funds even for basic equipment. Senior Court Service managers did not disagree with the broad thrust of this analysis. Indeed, the January consultation paper had spoken in similar terms. The judges described very clearly in their report the nature of the IT systems that were needed.

These were the problems. Part of the solution was to instal an IT infrastructure into all the main civil and family court centres, and to provide judges and court staff with the specialist software they needed so as to introduce order out of chaos. There were also plans for new business centres, so that undefended business could be dealt with somewhere else, and the court centres could concentrate on defended business. Part of my role as Judge in charge of Modernisation was to enthuse the judges with the idea that at very long last something was really going to happen. We ran a 24-hour seminar for 45 experienced circuit and district judges in the autumn of 2000 to tell them all about our plans. The prevailing sentiment was one of deep scepticism. A year later, Lord Woolf and the senior judiciary attended a similar seminar, at Warwick University. It seemed unimaginable that we would not at long last receive the IT support we had been promised.

The sceptics were right. In July 2002 the Treasury pulled the plug on all this. We had been allocated $£ 30$ million for the start of the programme in 2003-4, and this sum seemed to be carried forward each year until April 2006. In other words, it looked as if $£ 100$ million in all would be available, but without further funding we could not possibly complete the job and commission the specialist software we needed. The project team working on that part of the programme had to be disbanded immediately. In the event the limited funding was cut by a quarter. All we could do with the $£ 75$ million left was to provide an inferior IT infrastructure for civil and family courts conducting three quarters of that business, and to do our best to provide diary systems and other fairly basic tools from software designed for offices, not for courts. It was as if the British Airport Authority provided their airport counter staff with software suitable for preparing letters 
and minutes at head office. We also had to spend a lot of money upgrading the obsolete court databases.

In last year's book I described how after all that careful planning we appeared to have struck that long snake close to the top of the Snakes and Ladders Board. We were all sent back a very long way, and the morale of judges and court staff was badly shaken. On the evening of the spending review announcement in July 2002 the Treasury published a description of the objectives of the Lord Chancellor's Department. The modernisation of the civil and family courts did not rate a mention. It was obvious that most of the relief we hoped that technology would bring to civil and family court judges and their staff would not be forthcoming. Whether "jam tomorrow" would ever turn into "jam today" was back in the lap of the gods.

As things stand, none of our civil and family courts will have the benefit of the case management systems described in the judges' report, except in a fairly rudimentary form. It is common knowledge that CREST and CASEMAN do not possess the functionality to serve the linked diary and electronic case file, case management and case record systems that today's courts need, although efforts are being made to give these obsolete systems a slightly longer lease of life. The Royal Courts of Justice were identified as the flagship in the 2001 consultation paper. We are now having to do our best to spread a small amount of money as far as it will go. In the Court of Appeal, for instance, the staff in the Civil Appeals Office are unlikely to be able to access the new national network for another five years. During the whole of that period the judges and their clerks will not be using the same network as the staff who work for them.

A recently published book ${ }^{6}$ shows how in May 2002 the Deputy Head of Civil Justice, Lord Justice May, told an international seminar in this building of his fear that if in five years time the Court Service in this jurisdiction were not to have proper and sufficient information technology in support of civil litigation, it would be in danger of disintegrating. He said that the quality of service the administration was currently achieving depended on the good will of a number of overworked staff. Their morale was supported by an expectation that proper IT was around the corner, and expectation could not sustain morale indefinitely.

We are now nearly halfway through those five years. The LINK infrastructure is being rolled out to as many civil and family court centres as possible. This is good for morale, but it does not and cannot help staff and judges with the paper mountain. Even if we receive documents by email, we do not have the document management systems we thought we had been promised by 2004. Efforts are being made to adapt office systems to court use, but there is a limit to what can be achieved like this.

The other day I received a complaint from a solicitor handling a $£ 200,000$ claim which was transferred from the High Court to the Central London County Court. She said that at every stage the court system had let her and her client down. Staff in the High Court did not serve the claim form at all until inquiries were made a month later. Staff in the county court did not initiate the process whereby a judge immediately makes directions when a case is transferred. Instead they seem to have sent it back to the High Court, who sent it back again five months later.

When the county court directed mediation, a date was fixed one working day before the five-day trial was due to start. Close to that date one member of the court staff is said to have told the defendant's solicitor that the trial would be stayed for a four week period, while another member of staff was telling the claimant's solicitor the opposite. Eventually a judge adjourned the trial on the Friday on the representations of the defendant's solicitor made without notice. He was not informed that that very morning the claimant's solicitor had been telling court staff on the telephone that she must be allowed to make representations to the judge before any order was made. She was told that the judge must not be disturbed.

The trial was refixed to start on another Monday three months later. In the middle of the previous week the claimant's skeleton argument was delivered to the court office at one end of Park Crescent, Regent's Park. It had not reached the judge, at the other end of Park Crescent, by the time the trial opened. This happens frequently. At the start of the trial the judge complained in open court that he did not understand what the claim was all about. He had been able to pre-read the defendant's skeleton argument, but not the claimant's, although that was filed first. On the second day of the trial the claim was settled on the basis that the claimant might take $£ 40,000$ out of court. It took a struggle by the claimant's solicitor to achieve this 31 days later. She has described her ordeal in these terms:

"It was almost impossible to get the county court and the
Court Funds Office to cross-reference the matter. The county
court only seemed to have its own case number - no High
Court case number. The Court Funds Office only had the
High Court case number - and no trace of the county court
case number. As the lady at the Court Funds Office said, 'The
Central London County Court drove many people 'crazy' with
its mistakes...' It also sounded as though the full case
reference did not fit in the box on the court computer screen."

That solicitor has had over 30 years of litigation experience in England and Australia, and she is in a state of despair. Because she handled every aspect of the case herself, she could witness the problems that are bring caused to litigants and their advisers by a system of justice which is very, very seriously under-resourced. She told me that the experience of sitting in the foyer of that county court for a morning to listen to people struggling with the system might bring home just how bad things are. The court managers and the judges with management responsibilities are well aware of the scale of the problems, 
but they are like the little Dutch boy with his hand in the dyke.

Earlier this year the local designated civil judge made his frustrations public. He said that there are endemic weaknesses in managing a practically unlimited jurisdiction in the context of an infrastructure devised for an earlier age where any work of substance was dealt with by the High Court. At the heart of the problem, he said, is the inability of the Court Service to offer rates of pay that will secure the retention of experienced, competent staff in sufficient numbers, particularly in the inner cities. The Central London Civil Justice Centre, he said, loses about a third of its staff each year. More recently he has said that managers constantly have to move staff from jobs where they are beginning to make an impact, in order to cover for other staff. Junior managers of experience are very hard to come by.

I do not suggest, and I have never suggested, that investment in IT will provide a panacea to all these ills. What is needed is the implementation of the strategy of four years ago, limiting the work of the court centres to defended court business, and using the power of technology to transfer files electronically from one location to another as soon as a defence is filed.

I have already mentioned Money Claims Online. This excellent service was launched in February 2002. Simple money claims of up to $£ 100,000$ can be issued against up to two defendants. Within six months 75 claims were being processed every day. A year later the service was extended to enable defendants to respond on-line. More claims are now being issued through this on-line system than by the busiest of our county courts. Development work is now being done in connection with a possession claims service on the same lines, for use when tenants or mortgagors are in arrears with money payments. This should be piloted next year.

In a properly resourced civil justice system, the claim form and the notice of intention to defend could then be sent electronically to represent the beginnings of the electronic court file at the appropriate local court. Nowadays, even if that court is networked, the staff will have to print them out and place them in a paper file. I know that things do not have to be like this. Last year I visited courts in Singapore, Sydney and Melbourne where they are now using the court systems which I and others like me were advocating 15 years ago. A junior judge in Singapore showed me that he can access on his PC in his courtroom every document in the case. In Sydney, I was told that $60 \%$ of the users of their lands court are voluntarily using the new electronic filing facilities.

At the state of the art new county court building with 46 brand new criminal and civil courts in Melbourne I witnessed what was going on in the field of electronic documents management and electronic filing. All incoming documents were logged in to the court's electronic records system. There was a website which lawyers could access in order to check if a document had been filed. This had already greatly reduced the number of telephone inquiries court staff had to handle. In September 2003 an electronic filing system was to be made available to those who wished to use it. During my visit I also watched about 30 minutes of a video directions court where the directions judge was conducting a monthly case management list involving lawyers in a court three hours drive away from Melbourne. Her orders were prepared in court immediately and were available to the parties at either end almost immediately after she made them.

This is what can happen where there is a political desire to make it happen. Two years ago I visited the Immigration Appellate Authority's centre in Loughborough, where they handle asylum appeals from all over the country. There was a political determination that the staff should have the services they needed, and the atmosphere was every bit as positive as in those overseas courts. One team keyed in all the incoming material to a central database. Another team allocated the cases in blocks to hearing centres all round the country. Another team were responsible for recruiting and providing interpreters for every case that needed one. And there was a national call service there handling queries and complaints in a well-informed way. Staff worked in shifts between 9 am and 10 pm, they had excellent canteen and training facilities, and this service was being provided far more economically than would be possible in an expensive city centre. I imagine that in due course the documents in an appeal will be sent electronically to the relevant hearing centre

This was the model we hoped to develop for the civil and family courts in those heady days four years ago before the sky fell in on St Swithin's Day 2002, and the Treasury made it clear that any investment in modernisation would have to be paid for by litigants. Last month Lord Justice Thomas delivered a paper at Bangor University ${ }^{7}$ in which he traced the history of the warfare between the Treasury and successive Lord Chancellors since 1875 over who should bear the cost of the courts. In January 1965 Lord Gardiner beat off the Chief Secretary to the Treasury for six years. He told Mr Diamond that the country got its justice dirt cheap, when compared with continental systems of law. He also reminded him that Magna Carta said that we will not sell justice to the people. His letter ended "We really can't mess about with Magna Carta in Magna Carta year."

In 1992, however, against the background of the legal aid overspend, Magna Carta was indeed messed about. The Treasury got its way. From now on, every item of expenditure on the civil and family courts, judges, court buildings, IT infrastructure and all, had to be paid for by current litigants, subject to a very small public subsidy for the indigent and for family work. After ten years of these policies there was a $£ 160$ million backlog of essential court maintenance work in addition to the $£ 160$ million backlog of essential IT investment, and the courts had great 
difficulty in attracting and retaining the staff they needed to serve the judges properly.

What makes matters worse is that for very many years the High Court was subsidised by the huge profit it made on non-contentious probate work. This has now been stopped. Today, a large part of the courts' income is derived from the fees charged for undefended debt-collecting business which never goes anywhere near a judge. As the general volume of court business is falling, the general volume of that type of business is also falling. There are strong social pressures to find ways of diverting debt collecting work away from the courts. It is also declared Treasury policy to reduce the number of claims coming to court. This, too, will reduce the fee income.

And what will happen then? In giving the first lecture in this series six years ago, Lord Mackay said that he had never doubted that in a civilised society working under the rule of law, the courts were necessary for the compulsory adjudication of disputes and for bringing into action the compulsory enforcement procedure of the state. Without such mechanisms, he said, it was very difficult to imagine an effective rule of law. Nothing, he said, was more damaging than badly reproduced orders or the admission that the court file has been lost and that questions about a case cannot be answered.

Last Friday, I spent an hour at a London county court, talking to an experienced district judge about how things are now at the sharp end. From her answers I estimated that she was wasting at least a quarter of her time every day because the court's administrative systems were so poor.
This was due to the huge turnover in staff and junior managers, the obsolete IT and the antediluvian filing systems.

I have spent over forty years of my life in the world of civil justice. Two and a half years ago I really thought we were on the way to creating new arrangements for civil and family justice of which this country could be proud. Now I see no light on the horizon at all. I do not even see any evidence that the scale of the problem is being properly addressed because there are so many other initiatives currently being pursued, which are distracting the attention of our policy-makers. And so long as the Treasury insists on its full cost recovery regime, things can only get worse. Much worse. (c)

\footnotetext{
${ }^{1}$ Henry Brooke, "Technology and the Judicial Process", in Essays in Honour of Sir Brian Neill: the Quintessential Judge, (Mark Olliver Saville \& Richard E. Susskind eds., LexisNexis UK 2003).

${ }^{2}$ Civil Justice Review, Report of the Review Body on Civil Justice, June 1988, para 317.

${ }^{3}$ I have described these matters in greater detail in my paper entitled "The use of technology in the Courts", given to a seminar at Leeds University, and now published on the DCA website under "Speeches by Senior Judges"; and my article entitled "The Legal and Policy Implications of Courtroom Technology: the Emerging English experience", published in the William \& Mary Bill of Rights Journal, Vol 12, Issue 3, April 2004, p 699.

${ }^{4}$ See the website at http://www.courts.tas.gov.au/supreme/sentence/ comments_alpha.htm

${ }^{5}$ See endnote 1 above.

${ }^{6}$ The Future of Transnational Civil Litigation (Mads Andenas, Neil Andrews and Renato Nazzini eds), BIICL, 2004, p 46.

${ }^{7}$ The Sir Elwyn Jones Lecture, Bangor University, 8 October 2004, "The Maintenance of Local Justice", by Lord Justice Thomas, Senior Presiding Judge of England and Wales.
}

Lord Justice Brooke 